\title{
ANALISIS GAYA KEPEMIMPINAN DALAM MENINGKATKAN MOTIVASI KERJA PEGAWAI PADA DINAS PEKERJAAN UMUM KOTA KENDARI
}

\author{
Oleh: \\ Bakti ${ }^{1}$, La Ode Muhammad Elwan ${ }^{2}$ \\ 1,2 Dosen Fakultas Ilmu Sosial dan Ilmu Politik Universitas Halu Oleo \\ bakti.pascasarjana@gmail.com, muh.elwan@uho.ac.id
}

\begin{abstract}
Thus, this research aims to: (1) To know the leadership style of the Head of Department to improve the employee motivation in Kendari Public Works Department. (2) To know the work motivation of employees at the Kendari Public Works Department.

This research is qualitative research, which is research procedure that produces analytical description of the written word and the behavior of the object being observed. In this research, the determination of the informant set intentionally. Data was collected using three techniques, namely, observation, interviews and document analysis. The results showed that: 1) the dominant leadership style adopted by the Head of Department of Kendari Public Works is democratic leadership. This is based on interviews and analysis according to each indicator - free leadership style, autocratic, bureaucratic and undemocratic. All informants stated that the Head of the Kendari Public Works Department divide the tasks to subordinates in a fair and equitable, and using collaboration and discussion within the team to discuss the work and decision-making, this is in accordance with democratic leadership style indicator. While other leadership styles, there are several indicators that are not met. 2) Democratic leadership style adopted by the Kendari Head of the Public Works Department has not fully improved employee motivation. This is according to the results of the analysis and interviews on each indicator. As; still lack some office facilities and field facilies at the sub variable leadership attention on employee work environment; still a lack of employees who follow the Structural Training, take formal education (bachelor and master) on the sub variable provide opportunities for advanced. This is an indicator that can reduce the work motivation of employees of the Kendari City Public Works Department.
\end{abstract}

\section{Keywords : Leadership Style, The Work Motivation}

\section{PENDAHULUAN}

Seorang Kepala Dinas selaku pemimpin, khususnya pada Dinas Pekerjaan Umum Kota Kendari dalam memberikan motivasi kerja kepada para pegawai, seorang Kepala Dinas akan menunjukkan kecenderungan perilaku kepemimpinan atau penerapan gaya kepemimpinan tertentu, seperti menggunakan gaya kepemimpinan bebas, otokratis, birokratis dan demokratis. Hal ini dapat dilihat pada berbagai perilaku seorang Kepala Dinas dalam menjalankan pemerintahan sehari-hari.

Penerapan gaya kepemimpinan tertentu diharapkan mampu mengarahkan, menggerakkan, mempengaruhi serta memotivasi bawahannya untuk dapat melaksanakan tugas dengan baik, agar tidak terjadi berbagai penyimpangan dari tujuan yang ditetapkan semula. Faktor motivasi yang tinggi pada diri pegawai perlu selalu ditingkatkan, sehingga diperlukan kepemimpin dalam sebuah organisasi. Motivasi menjadi pendorong seseorang melaksanakan suatu kegiatan guna mendapatkan hasil yang terbaik. Oleh karena itulah tidak heran 
jika pegawai yang mempunyai motivasi kerja yang tinggi biasanya mempunyai kinerja yang tinggi pula. Untuk itu motivasi kerja pegawai perlu dibangkitkan agar pegawai dapat menghasilkan kinerja yang terbaik.

Di dalam kehidupan sehari-hari banyak gejala-gejala yang menyiratkan rendahnya semangat kerja seorang pegawai organisasi pemerintahan, antara lain; masih adanya anggota organisasi yang terlambat datang ke tempat kerja atau meninggalkan kantor sebelum waktunya. Pada saat jam kerja berlangsung, terdapat anggota organisasi yang tidak bekerja dan bahkan melakukan kegiatan yang tidak ada kaitannya dengan pekerjaannya. Dan masih banyak terlihat anggota organisasi yang menganggur daripada menyelesaikan pekerjaannya. Di samping itu, dilihat dari motivasi kerja pegawai, tampak masih rendahnya motivasi kerja pegawai. Hal ini terlihat dari rendahnya semangat pegawai untuk menyelesaikan pekerjaan sesuai dengan target yang telah ditetapkan. Hal ini berakibat pada rendahnya kinerja yang dimiliki pegawai yang terlihat dari sering terjadinya keterlambatan dalam penyelesaian pekerjaan.

Sebagai seorang pimpinan yang bertanggung jawab atas jalannya organisasi, perlu melakukan upayaupaya yang dapat menjadikan bawahannya bekerja dengan semangat tinggi, sehingga tujuan organisasi dapat tercapai. Motivasi ini dapat dilakukan dengan berbagai cara, antara lain memberikan pujian, memberikan penghargaan, memberikan insentif kepada pegawai yang mempunyai kinerja yang baik. Seorang pimpinan yang cenderung bersifat arogan, tidak mau tahu kondisi bawahan, tetapi tetap menginginkan para bawahan bekerja dengan baik. Hal itu akan sulit terlaksana, karena bawahan juga sebagai manusia, memerlukan dorongan, motivasi serta hubungan yang harmonis dari pimpinan.

Begitu pula pada Dinas Pekerjaan Umum Kota Kendari, dimana dalam mengukur berhasil atau tidak dalam mencapai tujuan sangat dipengaruhi beberapa faktor salah satunya adalah kelancaran penyelenggaraan pemerintahan yang didukung oleh birokrasi pemerintahan yang andal. Keberhasilan seorang Kepala Dinas dalam memotivasi para pegawai supaya dapat bekerja secara baik, terletak pada gaya kepemimpinan yang diterapkan dalam mengetahui dan memahami para bawahan yang ada dalam lingkungan organisasi.

Berdasarkan pengamatan yang dilakuka pada Dinas Pekerjaan Umum Kota Kendari, menunjukkan masih rendahnya motivasi kerja pegawai, hal ini terdapat beberapa fenomena yang dapat diidentifikasikan pada Dinas Pekerjaan Umum Kota Kendari adalah sebagai berikut; rendahnya motivasi kerja pegawai yang terlihat dengan masih banyak yang menggunakan jam kerja dengan aktivitas lain; kondisi lingkungan kerja yang masih kurang mendukung untuk meningkatkan motivasi kerja pegawai yang terlihat dengan kurang lengkapnya sarana dan prasarana pendukung kerja; dan, kurangnya kesempatan kepada pegawai dalam mengikuti pendidikan dan pelatihan, sehingga kualitas kinerja pegawai masih rendah.

Kondisi tersebut merupakan realitas yang dapat memperburuk fungsi pelayanan yang diberikan oleh pegawai pada rendahnya motivasi kerja pegawai yang terlihat dengan masih banyak yang menggunakan jam kerja dengan aktivitas lain, sehingga tentunya diperlukan penerapan gaya kepemimpinan seorang Kepala Dinas dalam meningkatkan motivasi kerja pegawai, khususnya pada Dinas Pekerjaan Umum Kota Kendari. Dari fenomena tersebut penulis tertarik untuk meneliti dan menganalisis lebih lanjut mengenai "Analisis Gaya Kepemimpinan Kepala Dinas Dalam Meningkatkan Motivasi Kerja Pegawai pada Dinas Pekerjaan Umum Kota Kendari". 


\section{TINJAUAN PUSTAKA}

\section{Konsep dan Teori Gaya Kepemimpinan}

Menurut Fleishman dalam Gibson (1990:263) mengemukakan tentang kepemimpinan sebagai suatu usaha mempengaruhi orang antar perorangan (interpersonal) lewat proses komunikasi, untuk mencapai sesuatu atau beberapa tujuan. Stogdill (1984:8) "Leadership as personality and its effects (Kepemimpinan adalah suatu kepribadian yang mempunyai pengaruh)". Selanjutnya menurut Pfiffner dalam Sudjana (2004:53) menyatakan "Leadership is the art of coordinating and motivating individuals and group to achive the desired end (Kepemimpinan adalah seni untuk mengkoordinasikan dan memberikan dorongan terhadap individu atau kelompok untuk mencapai tujuan yang diinginkan)".

Rustandi (1993:27) mengemukakan bahwa gaya kepemimpinan dibagi menjadi empat macam, yakni :

l) Gaya kepemimpinan otokratis; ditandai dengan banyaknya petunjuk yang datangnya dari pemimpin dan sangat terbatas bahkan tidak adanya peran serta anak buah dalam perencanaan dan pengambilan keputusan.

2) Gaya kepemimpinan birokratis; ditandai dengan keketatan pelaksanaan prosedur yang berlaku bagi pemimpin dan anak buahnya.

3) Gaya kepemimpinan demokratis; terjadi komunikasi dua arah, dimana pemimpin berkonsultasi dengan anak buahnya dalam merumuskan tindakan dan keputusan bersama.

4) Gaya kepemimpinan bebas; pemimpin sedikit sekali menggunakan kekuasaannya atau sama sekali membiarkan anak buahnya untuk berbuat sesuka hatinya. Dimana pemimpin sedikit sekali mempergunakan kekuasaannya.

Pendapat tersebut Rustandi membagi kepemimpinan menjadi empat macam, gaya kepemimpinan otokratis, birokratis, demokratis, dan bebas. Hal senada dikemukakan oleh Kencana (2003 : 27 - 3l) gaya kepemimpinan pemerintahan yaitu :

a) Gaya demokratis, yaitu cara dan irama seorang pemimpin pemerintahan dalam menghadapi bawahan dan masyarakat dengan memakai metode pembagian tugas dengan bawahan.

b) Gaya birokratis, yaitu cara dan irama seorang pemimpin pemerintahan dalam menghadapi bawahan dan masyarakat menggunakan metode tanpa pandang bulu.

c) Gaya kebebasan, yaitu cara dan irama seorang pemimpin pemerintahan dalam menghadapi bawahan dan masyarakatnya menggunakan metode pemberian keleluasaan pada bawahan seluas-luasnya.

d) Gaya otokratis, yaitu cara dan irama seorang pemimpin pemerintahan dalam menghadapi bawahan dan masyarakatnya menggunakan metode paksaan kekuasaan.

\section{Konsep dan Teori Motivasi}

Pace (2003:119) mengemukakan bahwa motivasi merujuk pada kondisi dasar yang mendorong seseorang untuk melakukan suatu tindakan. Kondisi dasar tersebut adalah kekurangan dan kebutuhan. Suatu kebutuhan adalah hal yang penting, tidak terhindarkan untuk memenuhi suatu kondisi. Istilah kebutuhan juga digunakan untuk merujuk kepada kekurangan terhadap sesuatu. Jadi, kebutuhan adalah suatu yang kurang dan harus dipenuhi.

Selanjutnya Riduwan (2002:34) mengemukakan bahwa dalam menilai motivasi kerja pengawai, pendekatan lokasi dapat di lakukan pada setiap kegiatan, karena kebiasaan seseorang cenderung tetap dalam pekerjaan sehari-hari. Jika pegawai mempunyai motif berkerja, hal ini dapat dibuktikan dari kebiasaan pegawai untuk 
melakukan pekerjaan tersebut baik di kantor maupun di lapangan. Dalam melakukan pekerjaan pegawai selalu dihadapkan pada motif, harapan dan insentif.

Selanjutnya menurut Scott dalam Gordon (1997:29) menyatakan bahwa :

1) Hilangnya motivasi karyawan apabila kesempatan untuk meraih prestasi hilang dan mereka menjadi peka terhadap kondisi lingkungan serta mulai mencari-cari kesalahan; dan

2) Apa yang membuat karyawan tidak puas ?, kebanyakan adalah faktor-faktor bukan pekerjaan sendiri (bersifat parifel atau sampingan) aturan kerja, penerangan, waktu istirahat, gelar, hak kesenioran, upah, tunjangan dan sebagainya.

Ditinjau dari sisi perilaku seseorang dalam kehidupan organisasi, menurut Suradinata (1996:138) bahwa paling sedikit ada sepuluh jenis kebutuhan yang sifatnya nonmaterial yang oleh para anggota oraganisasi dipandang sebagai hal yang turut mempengaruhi perilakunya dan yang menjadi faktor motivasional yang perlu dipuaskan dan oleh karenanya perlu mendapat perhatian bagi setiap pimpinan organisasi dalam mengendalikan pegawainya, yakni : Tempat kerja yang baik/memadai; Merasa diikutsertakan dalam bekerja; Memberikan suatu cara disiplin kerja yang manusiawi; Memberikan simpatik terhadap permasalahan pegawai; Memberikan rasa aman dalam bekerja, baik dalam pelaksanaan kerja maupun masa yang akan datang; Memberikan penghargaan bagi yang berprestasi, dan memberikan sanksi bagi yang salah; Menunjukkan kesetiaan kepada para pegawai; Memberikan promosi maupun penyegaran pegawai; Memberikan kesempatan untuk menambah ilmu pengetahuan kepada para pegawai; dan Memberikan informasi tentang kebijaksanaan organisasi dan memberikan pandangan terhadap kehidupan masa yang akan datang, agar hidup tenang dan sejahtera lahir batin.

\section{METODE PENELITIAN}

Desain penelitian; Lingkup penelitian ini adalah mengenai masalah-masalah ilmu administrasi negara. Penelitian ini adalah bersifat kualitatif dimana bertujuan untuk mengumpulkan data dari sejumlah individu/pegawai yang dapat mewakili individu/pegawai secara keseluruhan dan juga untuk memperoleh faktafakta dari gejala-gejala yang ada dan mencari keterangan secara aktual. Alasan digunakannya metode ini karena peneliti ingin mengetahui bagaimana gaya kepemimpinan Kepala Dinas dalam meningkatkan motivasi kerja pegawai.

Penentuan informan; Informan dalam penelitian ini adalah seluruh Pegawai Negeri Sipil yang dipilih secara purposive (sengaja), juga ditetapkan beberapa informan kunci yang dipilih secara sengaja (purposive).

Teknik pengumpulan data; ada tiga teknik pengumpulan data yang digunakan dalam penelitian kualitatif ini adalah pengamatan (observation), wawancara (interview), dan analisis dokumen (document analysis).

Teknik analisis data; Di dalam penelitian ini, untuk menganalisis data yang telah dikumpulkan dan diseleksi digunakan teknik analisis data deskriptif-kualitatif, yaitu data yang telah dihimpun dan dikumpulkan baik primer maupun sekunder selanjutnya disusun, dianalisis, diinterpretasikan untuk kemudian dapat diambil kesimpulan sebagai jawaban atas masalah yang diteliti. Pengambilan keputusan dalam penelitian ini dilakukan secara induktif yaitu dari data dan fakta yang khusus, peristiwa-peristiwa yang kongkret, kemudian dari fakta atau peristiwa yang khusus itu digeneralisasikan atau dianalisis ke tingkat abstraksi yang lebih tinggi dengan melakukan inteprestasi, mencari arti dan pengembangan yang lebih luas dari jawaban yang diberikan informan dengan menghubungkan ilmu pengetahuan dan teori yang sudah ada. Inteprestasi data sangat berpengaruh atau berhubungan dengan jawaban informan. 
Vol.2 No.2. July 2019. pp.43-51. Copyright@2019 Journal PUBLICUHO Faculty of Social and Political Sciences Halu Oleo University, Kendari, Southeast Sulawesi, Indonesia. e-ISSN: 2621-1351.Open Access at:

http://ojs.uho.ac.id/index.php/PUBLICUHO

Jounal publiuho is licensed under a Creative Commons Attribution 4.0 International License, which permits unrestricted use, distribution, and reproduction in any medium, provided the original work is properly cited.

\section{PEMBAHASAN}

\section{Gaya Kepemimpinan Kepala Dinas Pekerjaan Umum Kota Kendari}

\section{Gaya Kepemimpinan Bebas}

Berdasarkan pengamatan yang dilakukan Kepala Dinas Pekerjaan Umum Kota Kendari kurang memberikan keleluasaan kepada para pegawai untuk berbuat menurut keinginan masing-masing. Seluruh pegawai harus bertindak berdasarkan pada tugas pokok dan fungsi masing-masing dengan berdasarkan pada mekanisme maupun prosedur yang berlaku. Selanjutnya hasil wawancara juga menunjukan bahwa Kepala Dinas Pekerjaan Umum Kota Kendari tidak mengikuti segala kemauan atau keinginan para pegawai. Kemauan bawahan yang akan diikuti adalah dalam hubungannya dengan menciptakan sebuah solusi terhadap suatu persoalan yang dihadapi, dimana proses pengambilan keputusannya dilakukan bersama-sama. Hal ini bertentangan dengan gaya kepemimpinan bebas. Indikator kedua yang digunakan dalam menganalisis gaya kepemimpinan bebas Kepala Dinas Pekerjaan Umum Kota Kendari dalam realitasnya Kepala Dinas tidak mengikuti segala kemauan bawahan. Hal ini merupakan wujud sikap ketegasan dari Kepala Dinas Pekerjaan Umum Kota Kendari dalam menjalankan aktivitas organisasi. Kepala Dinas memberikan kesempatan kepada pegawai untuk menciptakan suatu kreativitas di dalam bekerja, selain itu pula Kepala Dinas dapat mengikuti atau melaksanakan suatu kemauan bawahan dalam rangka memecahkan suatu persoalan yang dihadapi oleh organisasi dimana proses pengambilan keputusannya dilaksanakan secara bersama-sama dengan selalu berlandaskan pada aturan organisasi.

\section{Gaya Kepemimpinan Otokratis}

Berdasarkan hasil penelitian di lapangan, Kepala Dinas Pekerjaan Umum Kota Kendari pemimpin mau menerima kritik, saran dan pendapat. Hal ini tentunya bertentangan dengan konsep gaya kepemimpinan otokratis, dimana pimpinan tidak mau menerima kritik, saran dan pendapat. Di dalam menjalankan roda organisasi Kepala Dinas Pekerjaan Umum Kota Kendari memberikan kesempatan kepada seluruh pegawai untuk memberikan kritik, saran maupun pendapat. Khususnya dalam proses pengambilan keputusan atas suatu persoalan yang dihadapi. Pada saat Dinas Pekerjaan Umum Kota Kendari dalam melaksanakan suatu proyek tertentu menghadapi persoalan teknis di lapangan, maka Kepala Dinas tidak akan mengambil keputusan sendiri atau bertindak berdasarkan pada kehendak pribadi, namun Kepala Dinas akan mendiskusikan dan meminta saran maupun pendapat kepada para bawahan terhadap suatu persoalan yang dihadapi. Hal ini dilakukan dalam rangka memininalisir terjadi kesalahan pengambilan keputusan.

Berdasarkan hasil wawancara menunjukkan bahwa Kepala Dinas Pekerjaan Umum Kota Kendari senantiasa menerima kritik, saran maupun pendapat yang disampaikan oleh pegawai, bahkan pimpinan secara sengaja akan meminta berbagai pandangan maupun saran-saran dari para bawahan atas segala persoalan yang dihadapi. Hal ini bertentangan dengan gaya kepemimpinan otokratis dimana ditandai dengan banyaknya petunjuk yang datangnya dari pemimpin dan sangat terbatas bahkan tidak adanya peran serta bawahan dalam perencanaan dan pengambilan keputusan.

Selanjutnya, indikator kedua yang digunakan dalam menganalisis gaya kepemimpinan otokratis Kepala Dinas Pekerjaan Umum Kota Kendari adalah pemimpin menggunakan metode paksaan kepada para pegawai. Berdasarkan hasil penelitian dapat diketahui bahwa Kepala Dinas Pekerjaan Umum Kota Kendari dapat menggunakan metode paksaan kepada pegawai, khususnya menyangkut penegakkan disipilin pegawai. Dimana metode paksanaan yang dimaksud adalah Kepala Dinas Pekerjaan Umum Kota Kendari selalu menekankan kepada seluruh pegawai untuk selalu memiliki tingkat disipilin yang baik dan senantiasa bekerja berdasarkan pada ketentuan yang berlaku. Dalam pemerintahan hal tersebut masih bisa dianggap wajar selama paksaan tersebut untuk kebaikan organisasi, karena seorang pemimpin juga dituntut untuk tegas, sehingga metode 
paksaan kekuasaanlah yang menjadi alatnya. Paksaan dilakukan tergantung situasi masih dinilai cukup baik dan dibandingkan karakteristik Gaya Kepemimpinan Otokratis yang dominan atau secara mutlak melakukan paksaan kekuasaan untuk menuruti semua apa yang menjadi keinginan pemimpin terhadap para bawahan.

Berdasarkan hal tersebut pada prinsipnya perilaku yang ditunjukkan oleh Kepala Dinas Pekerjaan Umum Kota Kendari bertentangan dengan pandangan yang dikemukakan oleh Kartono (2003 : 69), bahwa Tipe Otokratis menunjukkan sikap pimpinan lebih mengutamakan pada paksaan untuk menjalankan kekuasaan. Pemimpin yang mempunyai tipe ini, cenderung mempunyai keinginan untuk memegang kekuasaan selama-lamanya, absolut, dan ingin menjadi penguasa tunggal. Setiap kebijakan dan keputusan yang diambilnya tidak pernah dikonsultasikan dengan bawahannya akan selalu berdasarkan pada diri pribadinya.Selanjutnya Reddin (1997 : 59) mengemukakan gaya yang tidak efektif dalam kepemimpinan adalah gaya otokrat (autokrat), yakni gaya yang cenderung menggunakan gaya dedikasi pada situasi yang tidak menghendaki perilaku demikian, dimana pemimpin suka mengkritik dan mengancam, menuntut ketaatan pada bawahan, komunikasi satu arah dan ditakuti tetapi tidak disenangi oleh bawahan.

\section{Gaya Kepemimpinan Birokratis}

Berdasarkan hasil analisis menunjukkan bahwa Kepala Dinas Pekerjaan Umum Kota Kendari senantiasa menekankan kepada pegawai untuk memiliki tingkat kedisiplinan, tetapi dalam kenyataannya masih banyak pegawai yang memiliki kedisiplinan rendah yang dapat mempengaruhi efektivitas dan efisiensi organisasi. Kepala Dinas Pekerjaan Umum Kota Kendari memberikan pekerjaan sebagai tanggung jawab utama kepada pegawai berdasarkan pada kemampuan maupun spesialisasi kerja yang dimiliki. Dan Kepala Dinas Pekerjaan Umum Kota Kendari memperhatikan partisipasi bawahan, khususnya partisipasi dalam proses pengambilan keputusan terhadap berbagai persoalan yang terjadi baik di dalam maupun di luar organisasi, khususnya yang berhubungan dengan persoalan teknis pelaksanaan proyek di lapangan.

Di samping itu dari hasil analisis juga menunjukkan bahwa Kepala Dinas Pekerjaan Umum Kota Kendari belum secara maksimal menegakkan peraturan, khususnya di dalam pemberian sanksi kepada pegawai pada Dinas Pekerjaan Umum Kota Kendari. Kondisi ini bertentangan dengan pendapat Rustandi (1993:27) mengemukakan bahwa gaya kepemimpinan birokratis ditandai dengan keketatan pelaksanaan prosedur yang berlaku bagi pemimpin dan anak buahnya. Hal ini sejalan dengan pandangan menurut Kencana (2003 : 27 -31) gaya kepemimpinan birokratis, yaitu cara dan irama seorang pemimpin pemerintahan dalam menghadapi bawahan dan masyarakat menggunakan metode tanpa pandang bulu.

\section{Gaya Kepemimpinan Demokratis}

Kepala Dinas Pekerjaan Umum Kota Kendari memberikan pekerjaan kepada pegawai secara adil dan merata berdasarkan pada kemampuan dan keahlian masing-masing. Kepala Dinas Pekerjaan Umum Kota Kendari menggunakan kerja sama dan diskusi tim dalam membahas kerja dan pengambilan keputusan.

Berdasarkan hasil analisis yang dlakukan menunjukkan bahwa Dinas Pekerjaan Umum Kota Kendari mewujudkan perilaku sebagai seorang pimpinan yang demokratis di dalam menjalankan roda organisasi dalam rangka mencapai tujuan yang telah ditetapkan sebelumnya. Hal ini seperti yang dikemukakan oleh Rustandi (1993:27) mengemukakan bahwa gaya kepemimpinan demokratis terjadi komunikasi dua arah, dimana pemimpin berkonsultasi dengan anak buahnya dalam merumuskan tindakan dan keputusan bersama. Senada dengan Rustandi, menurut Kencana (2003 : 27 - 31) gaya demokratis, yaitu cara dan irama seorang pemimpin pemerintahan dalam menghadapi bawahan dan masyarakat dengan memakai metode pembagian tugas dengan bawahan. 
Vol.2 No.2. July 2019. pp.43-51. Copyright@2019 Journal PUBLICUHO Faculty of Social and Political Sciences Halu Oleo University, Kendari, Southeast Sulawesi, Indonesia. e-ISSN: 2621-1351.Open Access at:

http://ojs.uho.ac.id/index.php/PUBLICUHO

Jounal publiuho is licensed under a Creative Commons Attribution 4.0 International License, which permits unrestricted use, distribution, and reproduction in any medium, provided the original work is properly cited.

Motivasi Kerja Pegawai pada Dinas Pekerjaan Umum Kota Kendari

1. Pemberian Insentif

Kepala Dinas Pekerjaan Umum Kota Kendari selalu memberikan insentif kepada pegawai yang menunjukkan prestasi kerja di lapangan. Dimana pegawai mampu menyelesaikan pekerjaan sesuai sasaran yang telah ditetapkan sebelumnya, khususnya dalam RPJMD Dinas Pekerjaan Umum Kota Kendari.

\section{Perhatian Pemimpin terhadap Diri Pegawai}

Kepala Dinas Pekerjaan Umum Kota Kendari memperhatikan adanya iklim kerja yang kondusif tanpa ada konflik yang berlarut-larut sebab dapat mengganggu tercapainya program kerja organisasi. Bahwa Kepala Dinas Pekerjaan Umum Kota Kendari kurang memperhatikan kenaikan pangkat pegawai.

\section{Penempatan Pegawai pada Tempat yang Sesuai}

Kepala Dinas Pekerjaan Umum Kota Kendari memperhatikan pengalaman atau masa kerja pegawai dalam menempatkan pada jabatan struktural tertentu. Pegawai pada Dinas Pekerjaan Umum Kota Kendari, khususnya seluruh pejabat struktural telah ditempatkan sesuai dengan latar belakang pendidikan.

\section{Perhatian terhadap Lingkungan Kerja Pegawai}

Kepala Dinas Pekerjaan Umum Kota Kendari masih kurang memperhatikan ketersediaan beberapa fasilitas kerja yang dibutuhkan oleh pegawai, dimana kondisi ini dapat mempengaruhi motivasi kerja pegawai pada Dinas Pekerjaan Umum Kota Kendari. Fasilitas kerja yang tersedia belum sepenuhnya dipenuhi dalam mendukung pekerjaan pegawai. Kepala Dinas Pekerjaan Umum Kota Kendari belum sepenuhnya memperhatikan lingkungan kerja pegawai.

\section{Memberikan Kesempatan Untuk Maju}

Berdasarkan hasil wawancara menunjukkan bahwa Kepala Dinas Pekerjaan Umum Kota Kendari memberikan kesempatan kepada pegawai untuk melanjutkan pendidkan dan mengikuti Pendidikan dan Pelatihan Struktural.

\section{Gaya Kepemimpinan Dominan yang Diterapkan Kepala Dinas Pekerjaan Umum Kota Kendari dalam Meningkatkan Motivasi Pegawai}

Berdasarkan analisis pada masing-masing sub variabel gaya kepemimpinan, yakni gaya kepemimpinan bebas, otokratis, birokratis dan demokratis, maka dapat disimpulkan mengenai gaya dominan yang diterapkan oleh Kepala Dinas Pekerjaan Umum Kota Kendari, khususnya dalam meningkatkan motivasi kerja pegawai adalah gaya kepemimpinan demokratis. Penerapan gaya kepemimpinan ini tergambar dari berbagai analisis dan hasil wawancara dengan para informan berdasarkan pada masing-masing indikator yang telah disusun sebelumnya.

Pada gaya kepemimpinan bebas seluruh informan menyatakan bahwa Kepala Dinas Pekerjaan Umum Kota Kendari tidak memberikan keleluasaan kepada para bawahan untuk berbuat menurut keinginan pegawai, serta Kepala Dinas Pekerjaan Umum Kota Kendari mengikuti segala kemauan bawahan, hal ini tentunya bertentangan dengan gaya kepemimpinan bebas. Pada gaya kepemimpinan otokratis seluruh informan menyatakan bahwa Kepala Dinas Pekerjaan Umum Kota Kendari mau menerima kritik, saran dan pendapat, serta Kepala Dinas Pekerjaan Umum Kota Kendari tidak menggunakan metode paksaan kepada para pegawai, namun menunjukkan penegasan pada pelaksanaan disiplin pegawai, hal ini tentunya bertentangan dengan gaya kepemimpinan otokratis.

Begitupula gaya kepemimpinan birokratis seluruh informan menyatakan bahwa Kepala Dinas Pekerjaan Umum Kota Kendari menerapkan disiplin kerja, pembagian spesialisasi tugas khusus, dan memperhatikan partisipasi bawahan. Namun, Kepala Dinas Pekerjaan Umum Kota Kendari tidak tegas dalam pemberian sanksi kepada pegawai yang melakukan pelanggaran disiplin, khususnya disiplin waktu sebagaimana ketentuan perundangundangan yang berlaku, sehingga Kepala Dinas Pekerjaan Umum Kota Kendari kurang dominan menerapkan gaya kepemimpinan birokratis. Sedangkan gaya kepemimpinan demokratis seluruh informan menyatakan 


(C)
un
unrestricted use, distribution, and reproduction in any medium, provided the original work is properly cited.

bahwa Kepala Dinas Pekerjaan Umum Kota Kendari membagi tugas pada bawahan secara adil dan merata, serta Kepala Dinas Pekerjaan Umum Kota Kendari menggunakan kerja sama dan diskusi tim dalam membahas kerja dan pengambilan keputusan, hal ini sesuai dengan indikator gaya kepemimpinan demokratis, dimana Kepala Dinas Pekerjaan Umum Kota Kendari secara utuh dapat melaksanakan gaya kepemimpinan tersebut.

Seperti ungkapan seorang informan selaku sekretaris pada Dinas Pekerjaan Umum Kota Kendari pada wawancara sebagai berikut: "Kepala Dinas Pekerjaan Umum Kota Kendari pada prinsipnya di dalam menjalankan organisasi ini lebih bersikap demokratis kepada pegawai, hal ini tercermin dari perilaku dan perlakuan pimpinan kepada pegawai". (Wawancara, 2018).

Kepemimpinan pada dasarnya memiliki hubungan dengan motivasi kerja pegawai, hal ini berdasarkan pada pandangan menurut Pfiffner dalam Sudjana (2004 : 53) menyatakan "Leadership is the art of coordinating and motivating individuals and group to achive the desired end (Kepemimpinan adalah seni untuk mengkoordinasikan dan memberikan dorongan terhadap individu atau kelompok untuk mencapai tujuan yang diinginkan)". Dalam pandangan ini, menunjukkan bahwa kepemimpinan yang diterapkan di dalam organisasi merupakan sebuah upaya dalam memberikan dorongan atau motivasi kepada pegawai maupun tim kerja.

Pada pandangan lain dikemukakan oleh Pamudji (1989:123), bahwa salah satu gaya kepemimpinan adalah motivasi, yaitu pemimpin dalam menggerakkan orang-orang dengan mempergunakan motivasi baik yang merupakan imbalan ekonomis, dengan memberikan hadiah-hadiah (reward), jadi bersifat politis, maupun yang berupa ancaman hukuman (punish), jadi bersifat negatif. Pandangan ini senada yang diungkapkan oleh Reddin dalam Thoha (1997 : 57-58) dalam konsep gaya kepemimpinan efektif mengemukakan unsur pokok yang harus dilakukan oleh pemimpin, yakni seorang pemimpin yang memiliki motivator yang baik. Menggunakan partisipasi secara tepat, melalui koordinasi secara efektif dan mempergunakan kerja tim dalam mengambil keputusan.

\section{KESIMPULAN}

Berdasarkan pembahasan pada bab sebelumnya, maka dapat ditarik beberapa kesimpulan adalah sebagai berikut :

1. Gaya kepemimpinan dominan yang diterapkan oleh Kepala Dinas Pekerjaan Umum Kota Kendari adalah gaya kepemimpinan demokratis. Seluruh informan menyatakan bahwa Kepala Dinas Pekerjaan Umum Kota Kendari membagi tugas pada bawahan secara adil dan merata, serta Kepala Dinas Pekerjaan Umum Kota Kendari menggunakan kerja sama dan diskusi tim dalam membahas kerja dan pengambilan keputusan, hal ini sesuai dengan indikator gaya kepemimpinan demokratis. Sedangkan gaya kepemimpinan yang lain terdapat beberapa indikator yang tidak terpenuhi.

2. Gaya kepemimpinan demokratis yang diterapkan oleh Kepala Dinas Pekerjaan Umum Kota Kendari belum sepenuhnya meningkatkan motivasi kerja pegawai. Hal ini berdasarkan pada hasil analisis dan wawancara pada masing-masing indikator. Seperti; masih kurangnya beberapa fasilitas/sarana kantor dan di lapangan pada sub variabel perhatian pimpinan pada lingkungan kerja pegawai; masih kurangnya pegawai yang mengikuti Diklat Struktural, jenjang pendidikan pada sub variabel memberikan kesempatan untuk maju. 


\section{DAFTAR PUSTAKA}

Gibson, James L., 1990, Organisasi dan Manajemen, Erlangga, Jakarta

Gibson, Ivancecevich dan Donnely. 1996 Organisasi Perilaku struktur Proses. Terjemahan Nunuk Adiami. Jakarta : Bina Aksara.

Gordon, Thomas. 1997. Menjadi Pemimpin Efektif. Jakarta : PT Gramedia Pustaka Utama.

Kencana, Syafi'ie, 2003, Kepemimpinan Pemerintahan Indonesia, P.T. Refika Aditama, Bandung.

Pace, R. Wayne dan Don F. Faules, 2005. Komunikasi Organisasi, Strategi Meningkatkan Kinerja Perusahaan, Editor: Dedy Mulyana, PT. Remaja Rosdakarya, Bandung.

Robert, Angelo Kinicki. 2004. Organizational Behaviour (Sixth Edition). New York: The McGraw-Hill Companies, Inc

Rustandi R., Rachmat. 1993. Gaya Kepemimpinan. Bandung : CV Armico.

Sudjana. 2002. Metoda Statistika, Penerbit Tarsito, Bandung.

Suradinata, Ermaya. 1995. Psikologi Kepegawaian dan Peranan Pemimpin dalam Memotivasi Kerja. Bandung : Ramadan.

Suradinata, Ermaya. 1996. Manajemen Sumber Daya Manusia, Suatu Tinjauan Wawasan Masa Depan. Bandung : Ramadan.

Suradinata, Ermaya. 1997. Pemimpin dan Kepemimpinan Pemerintahan Pendekatan Budaya, Moral, dan Etika. Jakarta : PT Gramedia Utama.

Thoha, Miftah. 2001. Kepemimpinan dalam Manajemen Suatu Pendekatan Perilaku, RajaGrafindo Persada, Jakarta 